\title{
REVIEW
}

\section{The Hedgehog signalling pathway in breast development, carcinogenesis and cancer therapy}

\author{
Mun Hui ${ }^{1,+}$, Aurélie Cazet ${ }^{1,}$, Radhika Nair', D Neil Watkins², Sandra A O'Toole ${ }^{1,3,4,5}$ and Alexander Swarbrick,1,**
}

\begin{abstract}
Despite the progress achieved in breast cancer screening and therapeutic innovations, the basallike subtype of breast cancer (BLBC) still represents a particular clinical challenge. In order to make an impact on survival in this type of aggressive breast cancer, new targeted therapeutic agents are urgently needed. Aberrant activation of the Hedgehog $(\mathrm{Hh})$ signalling pathway has been unambiguously tied to cancer development and progression in a variety of solid malignancies, and the recent approval of vismodegib, an orally bioavailable small-molecule inhibitor of Smoothened, validates Hh signalling as a valuable therapeutic target. A number of recent publications have highlighted a role for $\mathrm{Hh}$ signalling in breast cancer models and clinical specimens. Interestingly, Hh ligand overexpression is associated with the BLBC phenotype and a poor outcome in terms of metastasis and breast cancer-related death. In this review, we provide a comprehensive overview of the canonical Hh signalling pathway in mammals, highlight its roles in mammary gland development and breast carcinogenesis and discuss its potential therapeutic value in BLBC.
\end{abstract}

\section{Introduction}

Breast cancer remains the leading cause of cancer-related death among women worldwide and accounts for $23 \%$ of all cancers diagnosed in 2008 [1], totalling approximately 1.4 million cases globally. With a lifetime risk of developing invasive breast cancer of 1 in 8 , breast cancer is one of the top three cancers that caused the greatest economic impact worldwide in 2008 [2]. Due to its frequency and

\footnotetext{
These authors contributed equally to this review

*Correspondence: a.swarbrick@garvan.org.au

'The Kinghorn Cancer Center and Cancer Res Division, Garvan Institute of Medical Research, Darlinghurst, NSW 2010, Australia

Full list of author information is available at the end of the article
}

cost, breast cancer represents a major public health concern.

Despite progress in early detection and adjuvant therapy, the outlook for women with locally advanced or metastatic disease remains bleak [1]. This may be due to a number of factors, including the molecular heterogeneity of breast tumours, intrinsic tumour resistance to conventional therapy, or inadequate therapy due to borderline pathological features. Extensive research has been carried out to understand breast carcinogenesis, and to develop new-targeted therapeutic agents and biomarkers to improve patient outcomes.

In recent years, the Hedgehog $(\mathrm{Hh})$ signalling pathway has emerged as a critical determinant of cancer initiation, progression and metastasis of an important subset of human cancers [3-5]. Recent studies have underlined an important though less understood function of the $\mathrm{Hh}$ pathway in breast cancer malignancy. This review will provide an update on the Hh signalling pathway and its role in the regulation of normal mammary development and the aetiology of breast cancer.

\section{Mechanisms of mammalian Hedgehog signalling}

The Hh pathway is an evolutionarily conserved system for regulating patterning and cell fate from Drosophila to humans. Hh proteins are secreted morphogens that play essential roles in regulation of embryogenesis, development, tissue homeostasis, regeneration and stem cell maintenance in a concentration-dependent manner [6]. Genetic or teratogenic disruption of Hh signalling during development in vertebrates results in a characteristic series of anomalies [4]. Perhaps most dramatic of these is holoprosencephaly, a congenital anomaly characterised by a failure of the embryonic forebrain to separate into two chambers. Normally, Hh ligand secreted by the notochord induces the ventral cell fate specification in the entire neural tube. Absence of this signal results in midline fusion of forebrain structures, including the optic vesicles, leading to cyclopia, a signature defect commonly associated with loss of function mutations in the $\mathrm{Hh}$ pathway [3,4]. In addition, aberrant Hh signalling in adults results in carcinogenesis, metastasis and chemoresistance [4]. 
Three mammalian Hh ligands have been identified, namely Sonic Hedgehog (SHH), Indian Hedgehog (IHH) and Desert Hedgehog (DHH) [3]. They are synthesised as $45 \mathrm{kDa}$ precursor proteins that are auto-processed into two fragments, an amino-terminal ( $\mathrm{HhN}$ ) and a carboxyterminal $(\mathrm{HhC})$ polypeptide. $\mathrm{HhN}$ mediates Hh signalling whereas the function of $\mathrm{HhC}$ is still not firmly established [7]. HhN is coupled to a cholesterol moiety at its carboxyl terminus as part of this processing reaction, and then undergoes palmitoylation at its amino terminus, mediated by the Hedgehog acyltransferase (HHAT) [3]. This process of dual lipid modification has important implications in intracellular trafficking, secretion and range of action of the Hh ligand. Subsequent release of $\mathrm{Hh}$ requires Dispatched (DISP), a large multipass transmembrane protein that transports the ligand across the plasma membrane [8].

In vertebrate species, Hh signalling requires an intact microtubule-based organelle named primary cilium. In the absence of ligand binding, the Hh receptor Patched $(\mathrm{PTCH})$ localises at the base of the primary cilium and constitutively inhibits pathway activity (Figure 1A). Binding of the processed and dual lipid-modified Hh ligand to PTCH abolishes the inhibitory effect of PTCH on Smoothened (SMO), the essential positive mediator of the entire pathway (Figure 1B). PTCH is a large 12-pass transmembrane protein of 1,500 amino acids [9]. There are two structurally related PTCH homologs in mammals, named PTCH1 and PTCH2. The amount of SHH available to bind $\mathrm{PTCH}$ is tightly regulated by Hh-binding proteins such as Hh-interacting protein (HHIP) and Growth arrest-specific gene (GAS1), which act as negative and positive regulators, respectively (Figure 1A) [10]. In parallel, $\mathrm{CDO}$ (Commodo) and BOC (Brother of Commodo) facilitate Hh-binding to PTCH1 in a calciumdependant manner [11]. Glypican-3, a member of the heparan sulfate proteoglycan family, interacts with high affinity to the Hh ligand and has also been implicated in inhibiting the Hh pathway by competing with PTCH for Hh binding [12]. Other proteins such as Megalin, Vitronectin, Perlecan, Scube2 and Shifted have been reported to bind Hh ligand in vertebrates but the nature and consequences of their interaction are not well understood [10].

Following binding of Hh ligand, the Hh-PTCH complex is internalised and SMO then moves from intracellular vesicles to the primary cilia, promoting Hh downstream signalling (Figure 1B). SMO is a 7-pass transmembranespanning protein with homology to G-protein-coupled receptors [13]. Activated SMO translocates to primary cilia at the cell membrane and in turn decouples Gliomaassociated oncoproteins (GLIs) from an inhibitory multiprotein proteolytic complex, leading to stabilisation of full length, transactivating GLI proteins (Figure 1B). The
GLI proteins, composed of three family members, GLI1 to GLI3, belong to the Kruppel family of zinc finger transcription factors. GLI1 acts exclusively as a transcriptional activator whereas GLI3 is mainly repressive [14]. GLI2 displays both activating and repressive functions, depending on the cellular context and the level of SMOregulated proteins [14]. The balance of the activator and repressor functions of these three GLI factors, the socalled 'GLI code', determines the status of the Hh transcriptional program and ultimately the behaviour of the responding cells [14]. Genomic analysis has identified several hundred GLI target genes, many of which can exhibit either a global (multiple Hh-responsive tissues) or a tissue/cell-specific pattern of expression [14]. However, a number of commonly identified targets have been characterised in detail. Apart from GLI, PTCH, and $H H I P$, the GLI1 and GLI2 proteins activate genes involved in cellular proliferation (CCND1/2, MYCN, SPP1, $B M I-1$, IGFBP6, FOXM1), survival (BCL2, MDM2), angiogenesis (VEGF, ANGPTL1/2, CYR61) and epithelialmesenchymal transition (BMP1, MUC5AC, SNAI1, JAG2) [15].

Although Hh signal transduction is dependent on the presence of an intact primary cilium in normal developing cells, the role of cilia in human tumour development and aggressiveness is more complex [16]. By using a transgenic model of ligand-driven Hh pathway activation, García-Zaragoza and collaborators [17] showed that the Hh-responding cells within the epithelial compartment of the mouse mammary gland are ciliated basal cells, which expand in response to the secretion of SHH ligand. In contrast, $\mathrm{SHH}$-expressing luminal cells rarely exhibit an intact primary cilium and therefore do not respond to Hh activation [17]. Other studies in mouse models demonstrated that primary cilia are either required for or inhibit tumour formation, depending on the nature of the oncogenic initiating event $[18,19]$. Ciliary ablation strongly inhibited the development of basal cell carcinoma (BCC) and medulloblastoma when these tumours were driven by an activated form of the transmembrane protein SMO. Conversely, removal of cilia accelerated tumourigenesis induced by constitutively active GLI2 $[18,19]$.

It is important to consider that 'non-canonical' $\mathrm{Hh}$ signalling, in which Hh pathway components signal outside of the HH-PTCH1-SMO-GLI paradigm, also occurs and can play important physiological roles, as reviewed by Jenkins [20]. At least three scenarios of noncanonical Hh signalling activation have been observed: 1) Hh signalling through $\mathrm{Hh}$ pathway members but independently to GLI-mediated transcription (for example, PTCH1 can act as a dependence-receptor, recruiting a protein complex in the absence of $\mathrm{HH}$ that ultimately enhances cell death through a caspase-9dependent mechanism [21]); 2) atypical interaction 


\section{A. Hedgehog pathway inactive}

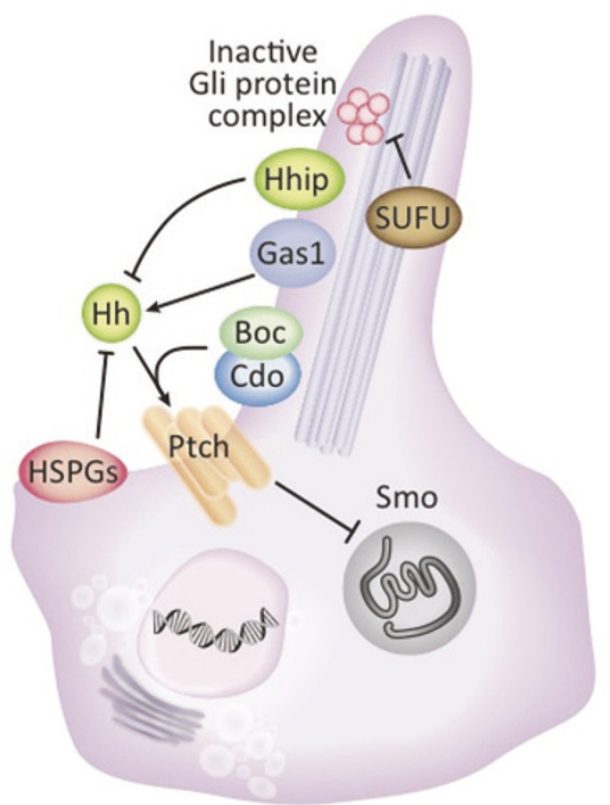

B. Hedgehog pathway active

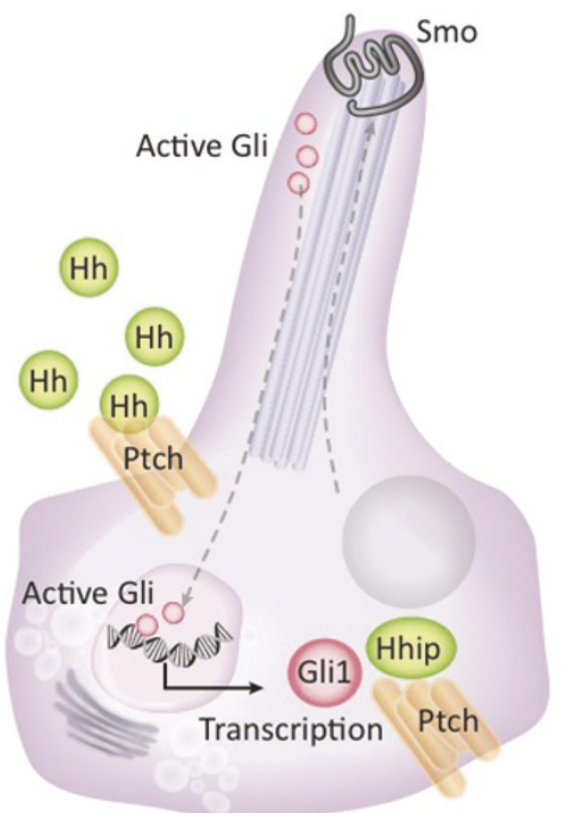

Figure 1. Model of the canonical Hedgehog signalling pathway in mammals. (A) In the absence of Hedgehog (Hh) ligand, the receptor Patched (Ptch) inhibits the activation of Smoothened (Smo) by preventing its surface translocation into the cilium. The Glioma-associated (GLI) proteins are phosphorylated and processed to truncated repressor forms. This inactive GLI protein complex functions as a transcriptional repressor of Hh target gene expression. Suppressor of fused (SUFU) inhibits GLI1 and GLI2 from entering the nucleus by sequestering the complex to the microtubules and represses transcription. (B) The binding of Hh ligands to Ptch releases the repression on Smo, leading to the movement of Smo from an intracellular vesicle to the tip of the primary cilium. Activated GLI proteins then translocate to the nucleus and promote the transcription of target genes. To note, Hh ligand binding is regulated by cell surface proteins: Hh-interacting protein (HHIP) and heparan sulfate proteoglycans (HSPGs) compete with the Hh-binding while GAS1 (Growth arrest-specific gene), Cdo (Commodo) and Boc (Brother of Commodo) proteins facilitate Hh-binding to Ptch.

between Hh pathway components; 3) crosstalk between Hh signalling and components of other molecular pathways [20]. Non-canonical signalling has functions in regulating cell motility, cell proliferation via activation of the cell cycle and in activating the programmed cell death [20]. Recent evidence has also defined a contribution of non-canonical Hh signalling in malignancy, and especially in breast cancer metastasis to bone [22].

\section{Role of Hedgehog signalling pathway in mammary gland development \\ Expression of the Hh pathway components during the mammary gland development}

Mammary gland development is unique in that it occurs predominantly in the postnatal period. While there are certain differences, mammary development in mice and humans is relatively similar, and the mouse has been extensively used as a model to define the role of $\mathrm{Hh}$ signalling in mammary development [23].

Mammary gland development can be divided into three phases - embryonic, non-parous and pregnant/ lactating [23]. Mammary gland development begins with the formation of rudimentary ductal trees that remain quiescent until the onset of puberty. During puberty in the mouse, terminal end buds (TEBs), bulb-shaped structures made up of multiple layers of immature, rapidly dividing epithelial cells, appear at the end of the ductal tree and generate secondary and tertiary branches. Once the ducts invade the mammary fat pads, the TEBs regress and proliferation ceases. Extensive lobuloalveolar development and differentiation occur during pregnancy, followed by milk production and secretion at parturition. Upon weaning, the alveolar epithelium undergoes apoptosis and the mammary gland is remodelled, returning to its mature virgin state [23].

Components of the Hh pathway have been identified in the mouse mammary gland during the embryonic, nonparous and pregnant phases. Although Shh and Ihh mRNA are detected within the mammary epithelium of mouse embryo, neither is required for bud development [24]. Microarray profiling of the mouse postnatal mammary gland reveals that Dhh is upregulated in TEBs 
compared to the stroma and ducts whereas Shh and Ihh are not [25], although the requirement for DHH in this process has not be examined. GLI1 expression is absent from mammary epithelium and mesenchyme. The repressor GLI3 is present in the epithelium and stroma whilst GLI2 is detected only in the stromal component during embryonic and non-parous phases of development $[26,27]$. During the pregnancy and lactation state, GLI2 is expressed within both the epithelial and the stromal compartment [27].

Despite the presence of these components, it appears that active Hh signalling is dispensable for mouse mammary gland morphogenesis both before and after birth. In fact, normal mammary gland development seems to be dependent on Hh pathway repression. Embryos that are null for either Gli1 or Gli2 have no obvious defects in mammary bud formation [26]. In contrast, constitutive activation of GLI1 or lack of functional GLI3 have individually resulted in failure of mammary bud formation in mouse models [26]. Additionally, overexpression of $\mathrm{SHH}$ in transgenic mouse embryos results in mammary bud anomalies, including the absence of mammary buds [28].

In pubertal mice, constitutive activation of SMO or heterozygous loss of PTCH1 results in morphologic TEB abnormalities, which are reminiscent of human ductal hyperplasia $[29,30]$. Further studies using phenotypic and transplantation analyses of mice carrying the mesenchymal dysplasia allele of patched 1 (Ptch1(mes)) revealed a failure of gland development, post-pubertal ductal elongation and delayed growth with ductal hyperplasia in these mice [30,31].

It has been also shown that the transcriptional repressor GLI2 cooperates with GLI3 in normal postnatal mouse mammary gland development. This theory is supported by the development of abnormal and distended branching in mice transplanted with Gli2-null glands [27]. GLI1 overexpression in mouse mammary epithelial cells leads to a defect in the complexity of the alveolar network, an inability to lactate and, importantly, the appearance of hyperplastic lesions and tumour development [32]. Finally, ciliary dysfunction in the mammary gland results in abnormal branching morphogenesis along with reduced lobular-alveolar development during pregnancy and lactation [33]. Altogether, these data demonstrate that de-regulation of $\mathrm{Hh}$ signalling can perturb mammary development and promote mammary carcinogenesis.

\section{Influence of Hedgehog signalling in the maintenance of mammary stem cells}

Delineation of the mammary stem cell hierarchy is still a work in progress. Visvader and colleagues [34] and Eaves and colleagues [35] provided the first evidence for a rare multipotent mammary stem cell identified by a combination of cell surface markers (CD24, CD29, CD44, CD49f and EpCAM). Recent genetic lineage-tracing experiments in mice enlighten our understanding of the cellular hierarchy of the mammary gland during development and in adult $[36,37]$. By using specific lineagetracing of the mammary gland in luminal or in myoepithelial cells, Van Keymeulen and collaborators [37] demonstrated the existence of long-lived unipotent basal and luminal stem cells that display extensive renewing capacities during puberty and the cycles of pregnancy and lactation.

Interestingly, these studies have also shed light on the cellular origin of breast cancer, with recent works demonstrating that luminal progenitors, rather than basal cells, can give rise to the basal-like subtype of breast cancer (BLBC) [37-39].

PTCH1, GLI1 and GLI2 genes are expressed in normal human mammary stem/progenitor cells cultured as mammospheres and are down-regulated during differentiation [40]. Activation of Hh signalling using $\mathrm{Hh}$ ligand or GLI1/GLI2 overexpression increases mammosphere formation, mammosphere size and multi-lineage progenitors, whereas inhibition of the pathway via cyclopamine results in a reduction of tumourigenic potential [40]. GLI1-induced tumours are histologically heterogeneous and involve the expansion of a population of epithelial cells expressing the putative progenitor cell marker cytokeratin 6 [41]. Hh effects on mammary stem cell self-renewal are associated with activation of the polycomb gene BMI-1 [40]. In parallel, activated human SMO under the mouse mammary tumour virus (MMTV) promoter in transgenic mice also increased the mammosphere-forming efficiency of primary mammary epithelial cells but decreased the frequency of regenerative stem cells in vivo, suggesting that enhanced mammosphere-forming efficiency is attributable to increased survival or activity of divisioncompetent cell types under anchorage-independent growth conditions [29].

Interestingly, intra-epithelial paracrine $\mathrm{Hh}$ signalling has been proposed to regulate the elaboration of the mammary progenitor compartment [42]. Hh ligand exerts a mitogenic effect on mammary stem cells, thereby activating the differentiation of mammary epithelial progenitor cells via differential TP63 promoter selection. Differential TP63 promoter usage underlies the specific expression of $\mathrm{IHH}$ ligand, which promotes further a positive feedback elaboration of mammary progenitors [42]. Enhanced $\mathrm{Hh}$ activity then plays a role during pregnancy-associated mammary gland expansion. Interestingly, emerging data have suggested that $\mathrm{Hh}$ signalling regulates cancer stem cells and could play a crucial role in carcinogenesis [43-46]. 


\section{Role of Hedgehog signalling pathway in breast carcinogenesis \\ Aberrant Hh signalling in cancer}

Two main mechanisms have been demonstrated for Hhmediated malignancy. Constitutive Hh signalling activation is due either to mutation of the Hh pathway components (ligand-independent) or through Hh overexpression (ligand-dependent) (Figure 2). GLI gene amplification was first reported in malignant glioma [47]. Subsequently, inactivating mutations in the $P T C H 1$ gene and activating SMO mutations were identified in BCC, medulloblastoma and rhabdomyosarcoma (Figure 2.1) [5]. Other Hh pathway components may also be genetically altered in human cancers, including SUFU, GLI1 and GLI3 [5]. In parallel, an expanding range of liganddependent cancers involving Hh overexpression has been identified in the past few years. Different models of Hh ligand-dependent activation have been demonstrated. Tumour cells can produce the Hh ligand and stimulate themselves in an autocrine/juxtacrine manner (Figure 2.2) or induce pathway activity within the neighbouring stromal cells in a paracrine manner (Figure 2.3B). Paracrine Hh signalling is then amplified by the fact that stromal cells secrete additional factors that promote tumourigenesis and survival of the tumour. Hh protein can also be produced by the stroma and stimulate the tumour cells, as demonstrated in multiple myeloma (Figure 2.3A) [48].

\section{Alterations in Hh pathway genes and components in breast cancer}

The potential role of Hh signalling in breast cancer is not well defined; however, recent studies have begun to shed light on its potential importance, particularly in aggressive subgroups such as triple-negative disease [49]. Early studies on small numbers of breast cancer samples showed rare mutation events in $\mathrm{SHH}$ and $\mathrm{PTCH}$ genes [50,51]. However, subsequent studies evaluating larger cohorts did not reveal any mutations in $\mathrm{SHH}, \mathrm{PTCH}$ or $S M O$ [52]. More recently, comparative genomic hybridisation analysis identified a frequent loss of PTCH1 locus and amplification of GLI1, independently of the breast tumour subtype [53,54]. Furthermore, a nonsynonymous mutation in $\mathrm{PTCH} 2$ has been described in the primary tumour and brain metastasis of a patient with BLBC [55]. However, a functional importance for any of these identified genetic anomalies requires further investigation in breast cancer.

Evidence for ligand-dependent breast carcinogenesis has been demonstrated by several groups. It was first reported when Kubo and colleagues [56] identified the expression of SHH, PTCH1 and GLI1 in invasive carcinomas but not in normal breast epithelium by immunohistochemistry. These data correlate with findings that our group recently published regarding a cohort of 292 human infiltrating ductal carcinomas [57]. We showed that different subsets of cancers express $\mathrm{Hh}$ ligand in the epithelium and/or stroma. Interestingly, we reported that epithelial Hh ligand expression is an early event in mammary carcinogenesis, strongly associated with a basal-like phenotype and poor outcome in terms of metastasis and breast cancer-related death [57]. We further demonstrated that ectopic expression of Hh ligand in a mouse model of BLBC led to the development of rapidly growing, high grade invasive tumours compared to controls [57].

Little is known about the mechanism underlying the up-regulation of the Hh ligand in solid malignancies, including breast cancer. $\mathrm{SHH}$ promoter region hypomethylation is frequently observed in breast carcinomas and is significantly associated with $\mathrm{SHH}$ up-regulation $[58,59]$. SHH gene transcription may not be solely dependent on promoter demethylation but could also be regulated by transcription factors [60]. A positive correlation between the expression of the transcription factor $\mathrm{NF}-\mathrm{kB}$ and $\mathrm{SHH}$ up-regulation was observed in breast clinical samples [59]. The transcription factors p63 (a homologue of the tumour suppressor protein p53) and Runx2 (a key factor for osteolytic metastasis induced by breast cancer cells) have also been found to regulate the expression of Hh ligands [61,62].

Several groups have evaluated the clinicopathological significance of $\mathrm{Hh}$ signalling in human breast neoplasms. A progressive increase in Hh expression and Hh pathway activation has been observed in lesions with greater cytological and atypical disease: from nonneoplastic masses to ductal carcinoma in situ (DCIS), DCIS with microinvasion, to invasive ductal carcinoma (IDC) $[57,63]$. Hh pathway activation also correlates with younger age of diagnosis ( $<50$ years), high proliferating index of Ki67, larger tumour size, invasion, lymph node metastasis, progesterone receptor-negative status and poorer overall survival [57,63,64]. Additionally, our laboratory also identified a strong correlation between Hh overexpression and BLBC. No association was found with any other subtype [57]. In parallel, Moraes and collaborators [29] observed a loss of expression of epithelial and stromal PTCH1 in approximately $50 \%$ of DCIS and IDC. Methylation of the PTCH promoter was further correlated with low PTCH1 expression in human breast neoplasms [58]. Conversely, SMO, undetectable in the normal tissue, was ectopically expressed in approximately $70 \%$ of DCIS and approximately $30 \%$ of IDC [29]. Recently, Ramaswamy and colleagues [65] demonstrated that the non-canonical Hh signalling is an alternative growthpromoting mechanism in tamoxifen-resistant breast tumours. 


\section{Ligand independent activation}

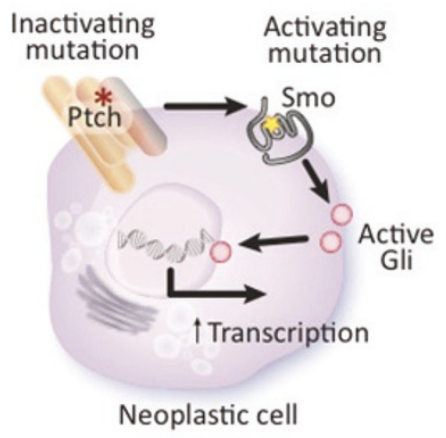

2. Ligand dependent autocrine activation

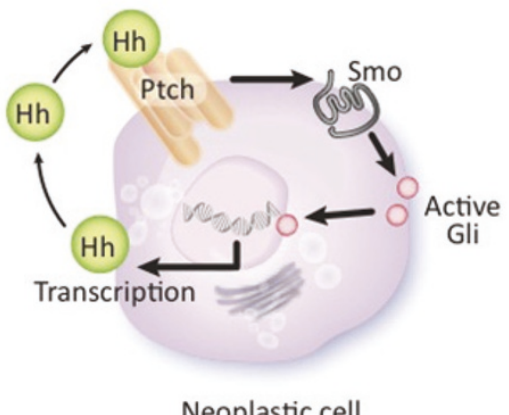

3. Ligand dependent paracrine activation

A.

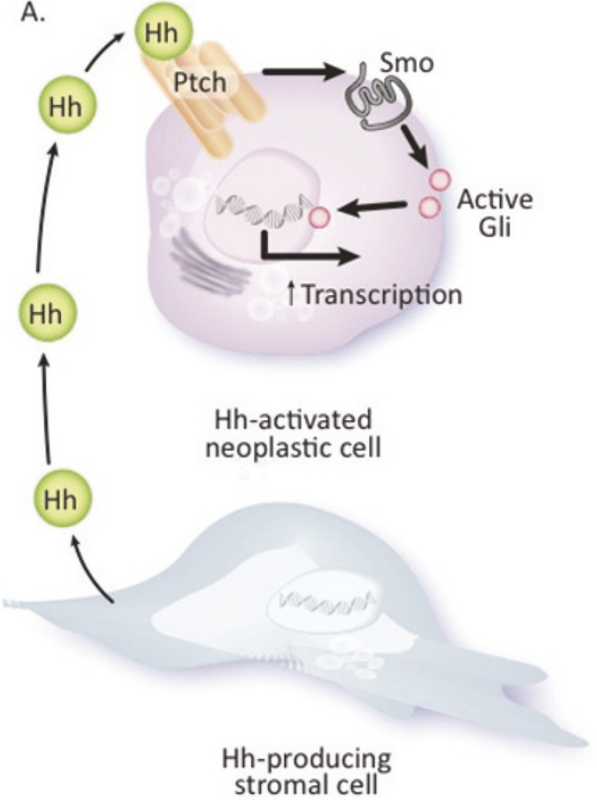

B.

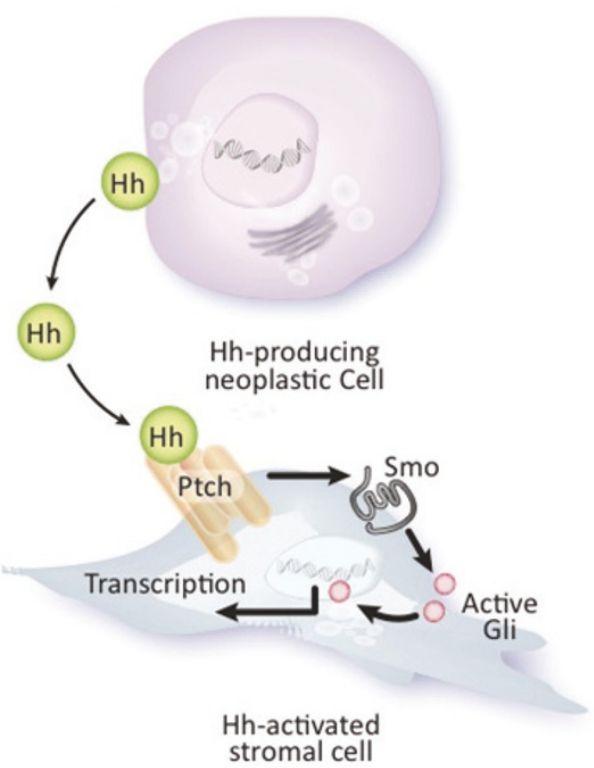

Figure 2. Three basic mechanisms of Hedgehog constitutive activation in cancer. 1. Hedgehog (Hh) ligand-independent signalling observed in basal cell carcinoma, medulloblastoma and rhabdomyosarcoma is caused by inactivating mutations in the Ptch1 gene (red asterisk) or activating Smo mutations (yellow star). It leads to the constitutive activation and transcription of the Hh target genes even in the absence of Hh ligand.

2. Hh ligand-dependent autocrine/juxtacrine activation observed in melanoma and lung cancers is associated with an over-expression of Hh ligand by the neoplastic cells, leading to a cell-autonomous stimulation. 3. Hh ligand-dependent paracrine activation is due to the over-secretion of Hh ligand by the non-malignant stromal (A) or the neoplastic cells (B). In the basal-like subtype of breast cancer, a crucial paracrine mode of canonical Hh signalling has been described by our group: the epithelial tumour cells secrete Hh ligand, leading to Hh pathway activation by the stroma. Stromal cells produce unknown additional growth or survival signals within the microenvironment that promote tumourigenesis (B). GLI, Gliomaassociated oncoprotein.

\section{A paracrine requirement for Hh signalling in many epithelial cancers}

Early studies suggested autocrine/juxtacrine Hh signalling in a variety of cancers, including small cell lung, gastric, colorectal, pancreatic, melanoma and prostate cancers. Significant evidence exists to support an important role for the Hh-GLI1 pathway within neoplastic cells in promoting growth, stem cell self-renewal and metastatic behaviour in advanced cancers [45,46,66-68]. For instance, tissue sections of metastatic melanoma showed expression of $S H H, P T C H 1$, and the three transcriptional mediators GLI1-3 specifically in melanocytes [68]. Similarly, GLI1 protein expression has been detected within the epithelial tumour mass of colon cancer both in the primary site and in liver metastases [46]. Interestingly, RNA interference-mediated knockdown of GLI1 or GLI2 in melanoma and colon cell lines or treatment with the $\mathrm{SMO}$ antagonist cyclopamine in vitro or as xenografts in 
vivo strikingly reduced tumour growth [45,46,66-68]. Recently, Park and collaborators [45] demonstrated that the Hh signalling acts within an autocrine/juxtacrine loop in small cell lung cancer, autonomously and independently of the lung cellular microenvironment.

However, given that the Hh pathway regulates embryogenesis through stromal-mesenchymal interaction, several recent publications have provided compelling evidence that $\mathrm{Hh}$ signalling operates through paracrine signalling between neoplastic cells and the tumour microenvironment in many cancers [69-71]. Yauch and colleagues [69] highlighted the paracrine requirement for Hh signalling in pancreatic primary tumours. Using a specific small molecule SMO antagonist, a neutralising anti-Hh antibody and genetic ablation of $S M O$ in the murine stroma, the investigators made the key observation that the secretion of $\mathrm{Hh}$ ligand by epithelial cells does not correlate with the expression of the Hh target genes in the tumour compartment but rather is associated with canonical activity in stromal cells. Co-culture of SHH-producing pancreatic cell lines with fibroblasts stably transfected with a GLI reporter construct results in the induction of GLI reporter activity in the fibroblasts. Surrounding stromal cells in turn may support tumour growth by secreting soluble factors, which remain to be determined. Additional evidence for a paracrine model of Hh signalling in cancer progression has been discussed comprehensively elsewhere [70,71].

In the context of breast cancer, paracrine Hh signalling appears to be an important mechanism by which $\mathrm{Hh}$ supports tumour growth. The epithelial breast tumour cells secrete Hh ligand, leading to Hh pathway activation by the stroma. Among the earliest pieces of evidence was the observation that whole mammary gland transplantation from Ptch1 heterozygous mice into athymic mice with intact PTCH1 maintained their dysplastic phenotype [30]. Conversely, transplantation of epithelium from Ptch1 heterozygous mice into wild-type cleared fat pad recipients resulted in the loss of dysplasia, suggesting a stromal requirement for PTCH1 [30]. Interestingly, similar observations were made with a Gli2-null mouse model, reinforcing the theory of Hh paracrine signalling in breast tumours [27]. Mammary luminal epithelial cells expressing a $S M O$ transgene stimulate specifically the proliferation of surrounding wild-type cells in a shortrange paracrine or juxtacrine manner, while the proliferation of SMO-positive cells themselves was not altered [72]. These results correlate with the observation that SMO-positive cells are rarely proliferative in DCIS and IDC samples [29].

Furthermore, analysis of Hh pathway localisation in primary breast cancers reveals that, in many cases, $\mathrm{SHH}$ and $\mathrm{DHH}$ ligands are expressed in the neoplastic epithelial cells rather than in stroma. In contrast, the expression of GLI1, GLI2 and SMO transcripts is considerably higher in fibroblasts than in epithelial cells [73]. Patients with evidence of such paracrine signalling have a poor prognosis phenotype [57]. Mouse models of BLBC also provide further evidence for paracrine signalling. The M6 cell line model of BLBC displays exclusively paracrine signalling in response to $\mathrm{Hh}$ overexpression in the epithelium [57]. Furthermore, treatment of mice carrying three different primary patient-derived BLBC xenografts with the Hh-neutralising antibody $5 \mathrm{E} 1$ led to reductions in GLI1 and PTCH1 expression in the mouse stromal cells but not in the human neoplastic cells (unpublished data) [74]. Other groups have also identified a potentially important role for Hh signalling in breast cancer. Harris and collaborators [75] validated our finding that over-expression of SHH in breast cancer cells promotes aggressive behaviour of xenografts, but in addition demonstrated that SHH through GLI1 upregulates a pro-angiogenic (VEGF-independent) secreted molecule, CYR61. Furthermore, silencing CYR61 in their triple-negative model attenuated the malignant phenotype associated with reduced tumour vasculature and less haematogenous spread [75]. These findings suggest a crucial paracrine mode of canonical Hh signalling in the progression and invasiveness of BLBC, although we cannot exclude autocrine signalling within other subsets of patients or a subpopulation of epithelial cells within cancers such as cancer stem cells.

\section{Role of Hh pathway in epithelial to mesenchymal transition and breast cancer metastasis}

The epithelial-to-mesenchymal transition (EMT) program is a biological process that allows polarised epithelial cells to become invasive and motile mesenchymal-like cells and has emerged as a topic of intense interest in breast cancer metastasis research [76]. Oncogenic EMT is linked to other pro-metastatic phenotypes, including resistance to chemo- and radiation therapy, self-renewal, evasion of the immune system and anoikis resistance [76]. Repression of E-cadherin expression by the action of several EMT-inducing transcription factors, such as Snail and Slug, is a critical step driving EMT. The expression of Snail correlates inversely with the prognosis of breast cancer patients [77]. The function of the Hh pathway in inducing EMT and invasion of breast cancer has not been well assessed. Ectopic expression of GLI1 induces the nuclear Snail expression and concomitant loss of E-cadherin expression in mouse mammary gland tissue during pregnancy [32]. Moreover, the transcription factor FOXC2 promotes mesenchymal differentiation during EMT via the Hh pathway and Snail up-regulation. FOXC2 is required for the ability of the BLBC subtype to metastasise specifically to the lung [78]. 
The Hh signalling pathway is associated with the metastatic process in a variety of solid malignancies $[19,46,67]$. Studies specific to Hh-mediated breast cancer metastasis have focused essentially on skeletal metastases. Complex paracrine signalling mediates osteolysis in the bone matrix, releasing cytokines such as transforming growth factor- $\beta$, which acts in a non-canonical manner $[22,79]$. GLI2 then induces the secretion of the parathyroid hormone-related protein (PTHrP), perpetuating a cycle of bone resorption and macrometastatic outgrowth $[22,79]$. Runx2, a transcription factor highly expressed in bone metastatic breast cancer cells, also mediates PTHrP activation through $\mathrm{IHH}$ up-regulation [61]. In parallel, the secretion of Hh ligand by breast tumour cells mediates a crosstalk with the bone environment in a paracrine manner, disrupting the homeostasis between the osteoclasts and osteoblasts [80,81]. Hh ligand activates the transcription of osteopontin (OPN) by the osteoclasts, promotes osteoclast maturation and resorptive activity, and facilitates osteoblast-enhanced osteolytic metastases [80-82]. Thus, colonisation of the bone metastatic site is facilitated by the cross-activation of the Hh pathway by breast cancer cells.

\section{Targeting the Hedgehog pathway in breast cancer The challenge of the basal-like subtype of breast cancer}

Despite advances in terms of radio-, chemo- and hormonal therapy, 20 to $30 \%$ of patients with early breast cancer will experience loco-regional recurrence with distant metastasis [83]. The BLBC subtype presents a particular clinical challenge. In general, patients with BLBC tend to have a higher rate of distant relapse after diagnosis, a rapid progression from distant recurrence to death, and only an approximately 50\% 10-year survival [84]. Much of the remarkable improvement in breast cancer outcome achieved in recent years is attributed to the use of targeted therapies inhibiting the oestrogen receptor (ER; tamoxifen) or HER2 (trastuzumab) in ER+ and HER2+ enriched subtypes, respectively. However, the majority of BLBC cases are negative for ER and HER2 expression and women who present with recurrent BLBC have usually failed standard adjuvant therapy. Thus, BLBC remains a subtype with a poor prognosis for which no targeted agents are clinically approved. In order to make an impact in survival on this type of aggressive breast cancer, there is an urgent need for new targeted therapeutic agents and companion biomarkers that are predictive of response.

\section{Hedgehog pathway antagonists}

The first naturally occurring $\mathrm{Hh}$ inhibitor identified was termed cyclopamine. Isolated from the wild corn lily Veratrum californicum, this steroidal alkaloid was discovered through investigations of one-eyed, or cyclopic, lambs whose mothers grazed on corn lily [85] (Table 1; Figure 3). Cyclopamine was the first to be shown to inhibit $\mathrm{Hh}$ signalling by binding SMO but did not represent a suitable therapeutic agent due to its poor bioavailability, short half-life, non-specific toxicity and chemical instability [86]. Several Hh inhibitors have been subsequently identified via large-scale chemical library screening approaches. In general, these compounds can be classified as specific inhibitors of Hh ligand, SMO or GLI transcription factors [5].

All of the small-molecule Hh pathway inhibitors that are currently investigated in phase I to III clinical trials target SMO. They include GDC-0449 (Erivedge/ vismodegib), LDE225, IPI-926, BMS-833923, itraconazole, PF-0444913, LEQ506 and TAK-441 (Figure 3; Table 1). All are very well tolerated with few dose-limiting side effects in adults. These inhibitors are in clinical trials either as monotherapy or in combination with other antineoplastic agents in a wide range of malignancies such as BCC, medulloblastoma, sarcoma, small cell lung carcinoma, and ovarian, prostate, pancreas, colon and haematological cancers [87]. Importantly, the small-molecule GDC-0449 (Curis Inc./Genentech) was approved in January 2012 by the United States Food and Drug Administration for the treatment of adults with locally advanced and metastatic BCC [88]. A multicenter phase II study involving $96 \mathrm{BCC}$ patients demonstrated overall response rates of $43 \%$ and $30 \%$ in patients with locally advanced and metastatic disease, respectively [89]. While the GDC-0449 antagonist has positive effects in BCC, clinical results in Hh ligand-dependent solid tumours have been less encouraging [90]. An additional challenge to the clinical use of $\mathrm{Hh}$ pathway antagonists is acquired resistance. For example, treatment of a PTCH1-mutant medulloblastoma patient with the small molecule GDC-0449 resulted in a rapid relapse due to an acquired tumour-specific mutation in SMO and the loss of interaction between the SMO mutant and the drug [91]. In order to overcome acquired resistance to SMO-targeting therapies, the second-generation HhAntag, Compound 5 and itraconazole (Sporanox ${ }^{\oplus}$, Johnson\&Johnson) agents have been developed and are in ongoing clinical trials (Figure 3) $[5,92,93]$. They prevent the Hh-induced accumulation of SMO in the primary cilium (Table 1).

The use of antagonists that target the $\mathrm{Hh}$ pathway downstream of SMO, such as GANT58 and GANT61, which blocks GLI transcriptional activity, represent an attractive therapeutic strategy in the context of resistance driven by SMO mutations. In vitro and in vivo studies of a number of malignancies treated with GANT61 have produced promising results [94]. Additionally, four new GLI antagonists have been identified in a large-scale, high-throughput screening by Hyman and collaborators [95]. Interestingly, recent preclinical evidence shows that 
Table 1. Hedgehog pathway inhibitors in preclinical studies and current clinical trials

\begin{tabular}{|c|c|c|c|c|c|c|c|}
\hline Classification & $\begin{array}{l}\text { Compound } \\
\text { (Company) }\end{array}$ & Origin & Target & Patient population & & $\begin{array}{l}\text { Development } \\
\text { stage }\end{array}$ & References \\
\hline \multirow{11}{*}{$\begin{array}{l}\text { Experimental } \\
\text { antagonists }\end{array}$} & Robotnikinin & Macrocycle & $\mathrm{HH}$ & - & & Preclinical & {$[88]$} \\
\hline & Cyclopamine & $\begin{array}{l}\text { Veratum } \\
\text { californicum }\end{array}$ & SMO & - & & Preclinical & {$[75,76]$} \\
\hline & HhAntag & $\begin{array}{l}\text { Benzimidazole } \\
\text { derivative }\end{array}$ & SMO & - & & Preclinical & [5] \\
\hline & Compound5 & Bis-amide class & $\mathrm{SMO}$ & - & & Preclinical & {$[82]$} \\
\hline & GANT58 & $\begin{array}{l}\text { Thiophene core } \\
\text { with four pyridine } \\
\text { rings }\end{array}$ & GLI & - & & Preclinical & {$[84]$} \\
\hline & GANT61 & $\begin{array}{l}\text { Hexahydro- } \\
\text { pyrimidine } \\
\text { derivative }\end{array}$ & GLI & - & & Preclinical & {$[84]$} \\
\hline & HIP1-4 & Unknown & GLI & - & & Preclinical & [85] \\
\hline & Zerumbone & Zingiber zerumbet & GLI & - & & Preclinical & {$[85]$} \\
\hline & Arcyriaflavin C & Arcyria ferruginea & GLI & - & & Preclinical & {$[85]$} \\
\hline & Physalin F & Physalis minima & GLI & - & & Preclinical & {$[85]$} \\
\hline & Arsenic trioxide & Arsenic & GLI & - & & Preclinical & {$[86,87]$} \\
\hline $\begin{array}{l}\text { Neutralising } \\
\text { antibody }\end{array}$ & $5 \mathrm{E} 1$ & Hybridomas & $\mathrm{HH}$ & - & & Preclinical & {$[40]$} \\
\hline \multirow[t]{8}{*}{$\begin{array}{l}\text { Small molecules } \\
\text { in current clinical } \\
\text { trials }\end{array}$} & $\begin{array}{l}\text { GDC-0449/ } \\
\text { Erivedge/ } \\
\text { vismodegib } \\
\text { (Genentech/ } \\
\text { Roche/Curis) }\end{array}$ & $\begin{array}{l}\text { Benzimidazole } \\
\text { derivate }\end{array}$ & SMO & Skin & $\begin{array}{l}\text { Basal cell } \\
\text { carcinoma } \\
\text { Basal cell nevus } \\
\text { syndrome } \\
\text { Breast }\end{array}$ & $\begin{array}{l}\text { Phase I-III (FDA } \\
\text { approved) }\end{array}$ & [77] \\
\hline & & & & $\begin{array}{l}\text { CNS/brain/head } \\
\text { and neck }\end{array}$ & $\begin{array}{l}\text { Medulloblastoma } \\
\text { Glioblastoma }\end{array}$ & & \\
\hline & & & & $\begin{array}{l}\text { Aero- and } \\
\text { gastrodigestive } \\
\text { tract }\end{array}$ & $\begin{array}{l}\text { Lung cancer } \\
\text { Oesophagus } \\
\text { Stomach } \\
\text { Colorectum } \\
\text { Pancreas }\end{array}$ & & \\
\hline & & & & Genital tract & $\begin{array}{l}\text { Ovarian } \\
\text { Prostate }\end{array}$ & & \\
\hline & & & & Blood & Multiple myeloma & & \\
\hline & & & & Soft tissue & Chondrosarcoma & & \\
\hline & LDE225 (Novartis) & Unknown & SMO & Skin & $\begin{array}{l}\text { Basal cell } \\
\text { carcinoma } \\
\text { Basal cell nevus } \\
\text { syndrome } \\
\text { Breast }\end{array}$ & Phase I-II & [77] \\
\hline & & & & $\begin{array}{l}\text { CNS/brain/head } \\
\text { and neck }\end{array}$ & $\begin{array}{l}\text { Medulloblastoma } \\
\text { Glioblastoma } \\
\text { Neuroblastoma } \\
\text { Astrocytoma }\end{array}$ & & \\
\hline
\end{tabular}


Hui et al. Breast Cancer Research 2013, 15:203

Page 10 of 14

http://breast-cancer-research.com/content/15/2/203

Table 1. Continued

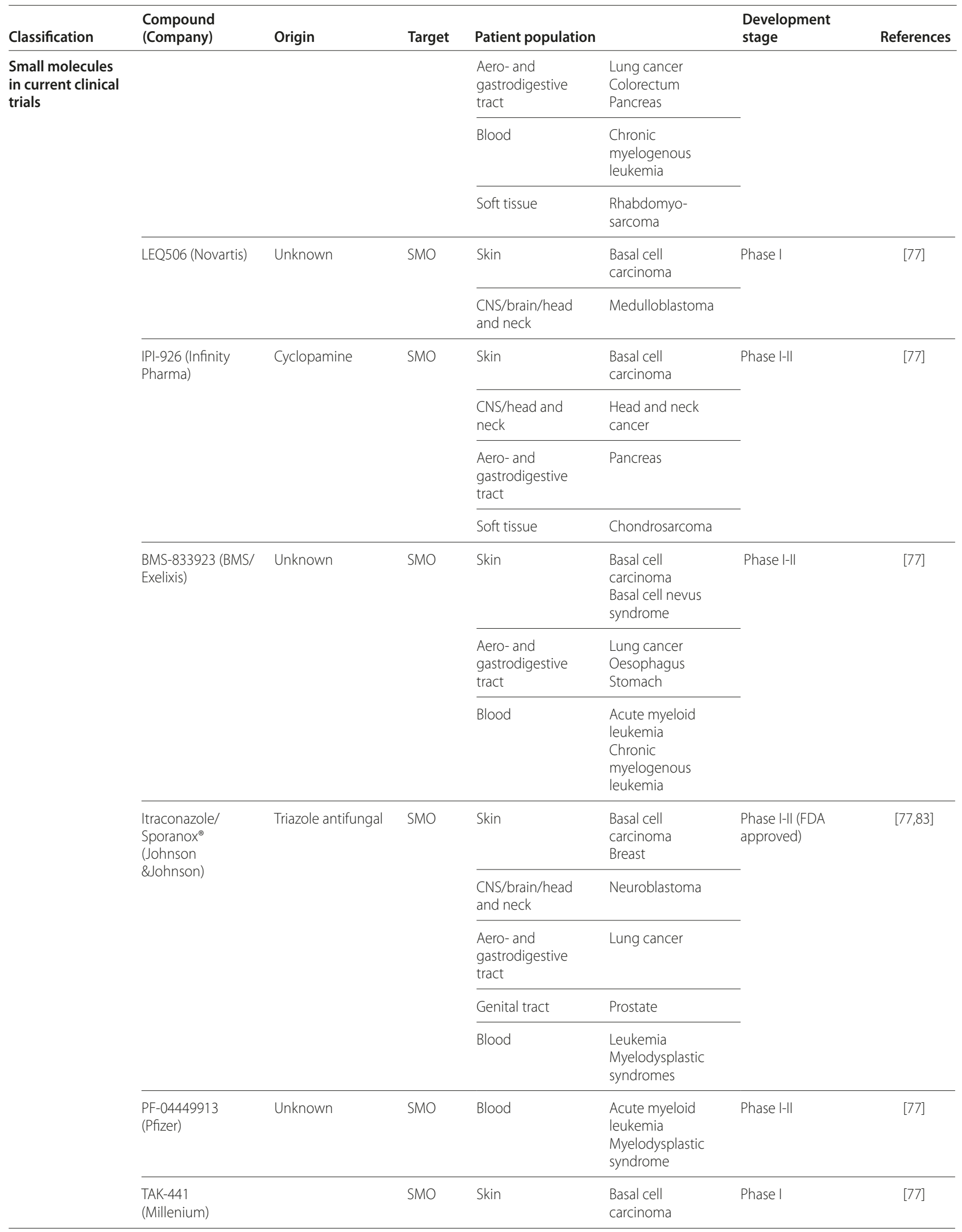

CNS, central nervous system; GLI, Glioma-associated oncoprotein; HH, Hedgehog; SMO, Smoothened. 


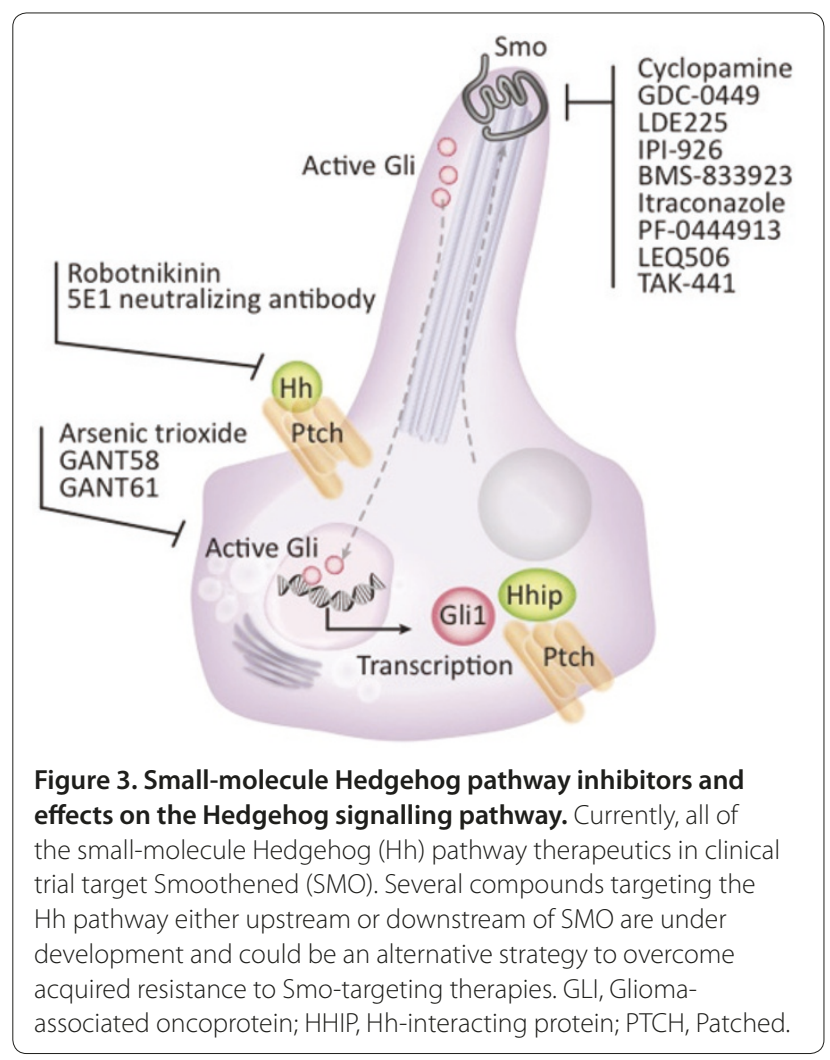

arsenic trioxide, a drug approved for the treatment of acute promyelocytic leukemia, inhibits the growth of Ewing sarcoma and medulloblastoma cells by targeting GLI proteins [96,97]. The outcome of clinical trials of these agents are much awaited for the evaluation of GLI inhibitors in the prevention and/or treatment of human malignancies. Inhibitors upstream of SMO include the small molecule robotnikinin and neutralising antibodies, directed against the Hh ligand (Figure 3; Table 1) [98].

\section{Inhibiting the hedgehog pathway in basal-like and metastatic breast cancer}

A number of experimental studies suggest that Hh signalling represents a tractable and efficient pharmacological target in BLBC and may further improve the efficacy of chemotherapy and/or radiation treatment, as has been suggested in oesophageal and pancreatic carcinomas [99]. There are already a number of clinical trials employing these strategies, notably in pancreatic and colorectal cancer [87]. Currently, one clinical trial of an Hh inhibitor has been conducted specifically in breast cancer, with GDC-0449 used in combination with a gamma-secretase inhibitor to treat women with advanced breast cancer (NCT01071564), but this trial has been suspended owing to side effects associated with this particular combination therapy. A phase I dose study of oral LDE225 in combination with the phosphatidylinositol-3-kinase inhibitor
BKM120 carried out by Novartis (NCT01576666) and a pilot trial of itraconazole pharmacokinetics (NCT00798135) are currently recruiting patients with metastatic breast cancer [87].

As has been the case with the development of many molecular targeted therapeutics for breast cancer, clinical success is dependent upon careful patient selection and appropriate combination therapy. This is best exemplified by trastuzumab, where development of a companion biomarker allowed clinical trials to find efficacy within the 10 to $15 \%$ of women with HER2-overexpressing disease [100]. When considering $\mathrm{Hh}$ as a therapeutic target for breast cancer, it is first important to characterise the cellular and molecular nature of the complex paracrine Hh signalling present in breast cancer, especially since the therapeutic target may be SMO expressed by the normal stromal cells rather than the neoplastic cells themselves. Equally important is the development of sensitive biomarkers of Hh pathway activation to identify the subset of cancers likely to respond to Hh-targeted therapeutics. Well-validated predictive biomarkers allow enrichment of the patient population for responders, sparing patients who are unlikely to respond to futile and potentially toxic therapy. Using GLI1 as a biomarker of Hh pathway activity, our own data suggest that approximately two-thirds of BLBC cases demonstrate evidence of paracrine Hh signalling [57], although such cases with evidence of paracrine signalling were seen across all subtypes of disease. However, GLI1 expression and activity are regulated by other signalling pathways, including Ras and transforming growth factor- $\beta$ in a SMO-independent fashion [101], making it an imprecise biomarker of Hh pathway activity.

\section{Conclusion}

In this review, we highlighted the current knowledge and recent findings regarding the involvement of the $\mathrm{Hh}$ developmental signalling pathway in breast development and carcinogenesis. The majority of evidence suggests that Hh signalling must be suppressed for appropriate mammary development and function. However, a number of clinical and experimental studies demonstrate that the Hh pathway is activated in a proportion of breast cancers and plays a critical role in aggressive breast cancers, including BLBC. Inhibiting this pathway in mouse models of triple-negative breast cancer dramatically decreases tumour growth and metastatic spread.

The microenvironment has long been known to play a key role in breast development and disease [102]. The Hh pathway is emerging as an important paracrine mediator by which cancer cells can remodel their stromal microenvironment. This has important implications for a novel therapeutic approach directed at the non-neoplastic stromal cells in the tumour as a complement to 
conventional cytotoxics and rationally designed therapies targeting the neoplastic cells. Given the availability of well tolerated agents targeting this pathway, Hh signalling is a tractable and promising therapeutic target to explore in breast cancer. Developments in this area may offer hope to women with poor prognosis breast cancer.

\section{Abbreviations}

BCC, basal cell carcinoma; BLBC, basal-like subtype of breast cancer; DCIS, ductal carcinoma in situ; DHH, Desert Hedgehog; EMT, epithelial-tomesenchymal transition; ER, oestrogen receptor; GLI, Glioma-associated oncoprotein; Hh, Hedgehog; HHIP, Hh-interacting protein; IDC, invasive ductal carcinoma; IHH, Indian Hedgehog; PTCH, Patched; PTHrP, parathyroid hormone-related protein; SHH, Sonic Hedgehog; SMO, Smoothened; TEBS, terminal end buds.

\section{Competing interests}

AS received research funding and was financially supported to attend an interstate research symposium by Novartis Pharmaceuticals (Basel, Switzerland) in 2012. SAT is a member of Roche Pharmaceuticals (Castle Hill, Australia) molecular pathology advisory board and in 2012 was sponsored to attend a local research symposium by Roche Pharmaceuticals. Neither organization stands to directly gain from the publication of this review nor are they financing this manuscript. All other authors declare no competing interests.

\section{Acknowledgements}

We thank Drs Darren Saunders and Andrew Franklin for critical reading of the manuscript. This work was supported by the National Health and Medical Research Council (grant ID APP1050693 and a Fellowship to AS), the Cancer Institute New South Wales (Translational Program Grant 10/TPG/1-04 and Fellowship 10/CRF/1-07 to SAO'T) and the Sydney Breast Cancer Foundation (SAO'T).

\section{Author details}

'The Kinghorn Cancer Center and Cancer Res Division, Garvan Institute of Medical Research, Darlinghurst, NSW 2010, Australia. ${ }^{2}$ Monash Institute of Medical Research, Monash University, Clayton, Victoria 3168, Australia. ${ }^{3}$ St Vincent's Clinical School, Faculty of Medicine, University of New South Wales, NSW 2052, Australia. ${ }^{4}$ Department of Tissue Pathology and Diagnostic Oncology, Royal Prince Alfred Hospital, Camperdown, NSW 2050, Australia.

${ }^{5}$ Sydney Medical School, University of Sydney, NSW 2006, Australia.

Published: 28 March 2013

\section{References}

1. Ferlay J, Shin HR, Bray F, Forman D, Mathers C, Parkin DM: Estimates of worldwide burden of cancer in 2008: GLOBOCAN 2008. Int J Cancer 2010, 127:2893-2917.

2. American Cancer Society: The Global Economic Cost of Cancer [http://www.cancer.org/acs/groups/content/@internationalaffairs/ documents/document/acspc-026203.pdf]

3. Varjosalo M, Taipale J: Hedgehog: functions and mechanisms. Genes Dev 2008, 22:2454-2472

4. Mullor JL, Sanchez P, Ruiz i Altaba A: Pathways and consequences: Hedgehog signaling in human disease. Trends Cell Biol 2002, 12:562-569.

5. Ng JM, Curran T: The Hedgehog's tale: developing strategies for targeting cancer. Nat Rev Cancer 2011, 11:493-501.

6. Hooper JE, Scott MP: Communicating with Hedgehogs. Nat Rev Mol Cell Biol 2005, 6:306-317.

7. Porter JA, von Kessler DP, Ekker SC, Young KE, Lee JJ, Moses K, Beachy PA: The product of hedgehog autoproteolytic cleavage active in local and long-range signalling. Nature 1995, 374:363-366.

8. Burke R, Nellen D, Bellotto M, Hafen E, Senti KA, Dickson BJ, Basler K: Dispatched, a novel sterol-sensing domain protein dedicated to the release of cholesterol-modified hedgehog from signaling cells. Cell 1999, 99:803-815.

9. Hahn H, Christiansen J, Wicking C, Zaphiropoulos PG, Chidambaram A, Gerrard B, Vorechovsky I, Bale AE, Toftgard R, Dean M, Wainwright B: A mammalian patched homolog is expressed in target tissues of sonic hedgehog and maps to a region associated with developmental abnormalities. J Biol Chem 1996, 271:12125-12128.

10. Beachy PA, Hymowitz SG, Lazarus RA, Leahy DJ, Siebold C: Interactions between Hedgehog proteins and their binding partners come into view. Genes Dev 2010, 24:2001-2012.

11. McLellan JS, Zheng X, Hauk G, Ghirlando R, Beachy PA, Leahy DJ: The mode of Hedgehog binding to Ihog homologues is not conserved across different phyla. Nature 2008, 455:979-983.

12. Capurro MI, Xu P, Shi W, Li F, Jia A, Filmus J: Glypican-3 inhibits Hedgehog signaling during development by competing with patched for Hedgehog binding. Dev Cell 2008, 14:700-711

13. Alcedo J, Ayzenzon M, Von Ohlen T, Noll M, Hooper JE: The Drosophila smoothened gene encodes a seven-pass membrane protein, a putative receptor for the hedgehog signal. Cell 1996, 86:221-232.

14. Stecca B, Ruiz IAA: Context-dependent regulation of the GLI code in cancer by HEDGEHOG and non-HEDGEHOG signals. J Mol Cell Biol 2010, 2:84-95.

15. Harris $L G$, Samant RS, Shevde LA: Hedgehog signaling: networking to nurture a promalignant tumor microenvironment. Mol Cancer Res 2011, 9:1165-1174.

16. Huangfu D, Liu A, Rakeman AS, Murcia NS, Niswander L, Anderson KV: Hedgehog signalling in the mouse requires intraflagellar transport proteins. Nature 2003, 426:83-87.

17. Garcia-Zaragoza E, Perez-Tavarez R, Ballester A, Lafarga V, Jimenez-Reinoso A, Ramirez A, Murillas R, Gallego MI: Intraepithelial paracrine Hedgehog signaling induces the expansion of ciliated cells that express diverse progenitor cell markers in the basal epithelium of the mouse mammary gland. Dev Biol 2012, 372:28-44.

18. Wong SY, Seol AD, So PL, Ermilov AN, Bichakjian CK, Epstein EH Jr, Dlugosz AA, Reiter JF: Primary cilia can both mediate and suppress Hedgehog pathway-dependent tumorigenesis. Nat Med 2009, 15:1055-1061.

19. Han YG, Kim HJ, Dlugosz AA, Ellison DW, Gilbertson RJ, Alvarez-Buylla A: Dual and opposing roles of primary cilia in medulloblastoma development. Nat Med 2009, 15:1062-1065.

20. Jenkins D: Hedgehog signalling: emerging evidence for non-canonical pathways. Cell Signal 2009, 21:1023-1034

21. Mille F, Thibert C, Fombonne J, Rama N, Guix C, Hayashi H, Corset V, Reed JC, Mehlen P: The Patched dependence receptor triggers apoptosis through a DRAL-caspase-9 complex. Nat Cell Biol 2009, 11:739-746.

22. Johnson RW, Nguyen MP, Padalecki SS, Grubbs BG, Merkel AR, Oyajobi BO, Matrisian LM, Mundy GR, Sterling JA: TGF-beta promotion of Gli2-induced expression of parathyroid hormone-related protein, an important osteolytic factor in bone metastasis, is independent of canonical Hedgehog signaling. Cancer Res 2011, 71:822-831.

23. Watson CJ, Khaled WT: Mammary development in the embryo and adult: a journey of morphogenesis and commitment. Development 2008, 135:995-1003.

24. Michno K, Boras-Granic K, Mill P, Hui CC, Hamel PA: Shh expression is required for embryonic hair follicle but not mammary gland development. Dev Bio/ 2003, 264:153-165.

25. Kouros-Mehr H, Werb Z: Candidate regulators of mammary branching morphogenesis identified by genome-wide transcript analysis. Dev Dynamics 2006, 235:3404-3412.

26. Hatsell SJ, Cowin P: Gli3-mediated repression of Hedgehog targets is required for normal mammary development. Development 2006, 133:3661-3670.

27. Lewis MT, Ross S, Strickland PA, Sugnet CW, Jimenez E, Hui C, Daniel CW: The Gli2 transcription factor is required for normal mouse mammary gland development. Dev Biol 2001, 238:133-144.

28. Gritli-Linde A, Hallberg K, Harfe BD, Reyahi A, Kannius-Janson M, Nilsson J, Cobourne MT, Sharpe PT, McMahon AP, Linde A: Abnormal hair development and apparent follicular transformation to mammary gland in the absence of hedgehog signaling. Dev Cell 2007, 12:99-112.

29. Moraes RC, Zhang X, Harrington N, Fung JY, Wu MF, Hilsenbeck SG, Allred DC, Lewis MT: Constitutive activation of smoothened (SMO) in mammary glands of transgenic mice leads to increased proliferation, altered differentiation and ductal dysplasia. Development 2007, 134:1231-1242.

30. Lewis MT, Ross S, Strickland PA, Sugnet CW, Jimenez E, Scott MP, Daniel CW: Defects in mouse mammary gland development caused by conditional haploinsufficiency of Patched-1. Development 1999, 126:5181-5193.

31. Moraes RC, Chang H, Harrington N, Landua JD, Prigge JT, Lane TF, Wainwright $\mathrm{BJ}$, Hamel PA, Lewis MT: Ptch1 is required locally for mammary gland 
morphogenesis and systemically for ductal elongation. Development 2009, 136:1423-1432.

32. Fiaschi M, Rozell B, Bergstrom A, Toftgard R, Kleman Ml: Targeted expression of GLI1 in the mammary gland disrupts pregnancy-induced maturation and causes lactation failure. J Biol Chem 2007, 282:36090-36101.

33. McDermott KM, Liu BY, TIsty TD, Pazour GJ: Primary cilia regulate branching morphogenesis during mammary gland development. Curr Biol 2010, 20:731-737

34. Shackleton M, Vaillant F, Simpson KJ, Stingl J, Smyth GK, Asselin-Labat ML, Wu L, Lindeman GJ, Visvader JE: Generation of a functional mammary gland from a single stem cell. Nature 2006, 439:84-88.

35. Stingl J, Eirew P, Ricketson I, Shackleton M, Vaillant F, Choi D, Li HI, Eaves CJ: Purification and unique properties of mammary epithelial stem cells. Nature 2006, 439:993-997.

36. Blanpain C: Tracing the cellular origin of cancer. Nat Cell Bio/ 2012, 15:126-134

37. Van Keymeulen A, Rocha AS, Ousset M, Beck B, Bouvencourt G, Rock J, Sharma N, Dekoninck S, Blanpain C: Distinct stem cells contribute to mammary gland development and maintenance. Nature 2011, 479:189-193.

38. Molyneux G, Geyer FC, Magnay FA, McCarthy A, Kendrick H, Natrajan R, Mackay A, Grigoriadis A, Tutt A, Ashworth A, Reis-Filho JS, Smalley MJ: BRCA1 basal-like breast cancers originate from luminal epithelial progenitors and not from basal stem cells. Cell Stem Cell 2010, 7:403-417.

39. Lim E, Vaillant F, Wu D, Forrest NC, Pal B, Hart AH, Asselin-Labat ML, Gyorki DE, Ward T, Partanen A, Feleppa F, Huschtscha LI, Thorne HJ; kConFab, Fox SB, Yan M, French JD, Brown MA, Smyth GK, Visvader JE, Lindeman GJ: Aberrant luminal progenitors as the candidate target population for basal tumor development in BRCA1 mutation carriers. Nat Med 2009, 15:907-913.

40. Liu S, Dontu G, Mantle ID, Patel S, Ahn NS, Jackson KW, Suri P, Wicha MS: Hedgehog signaling and Bmi-1 regulate self-renewal of normal and malignant human mammary stem cells. Cancer Res 2006, 66:6063-6071.

41. Fiaschi M, Rozell B, Bergstrom A, Toftgard R: Development of mammary tumors by conditional expression of GLI1. Cancer Res 2009, 69:4810-4817.

42. Li N, Singh S, Cherukuri P, Li H, Yuan Z, Ellisen LW, Wang B, Robbins D, DiRenzo J: Reciprocal intraepithelial interactions between TP63 and hedgehog signaling regulate quiescence and activation of progenitor elaboration by mammary stem cells. Stem Cells 2008, 26:1253-1264.

43. Zhao C, Chen A, Jamieson CH, Fereshteh M, Abrahamsson A, Blum J, Kwon HY, Kim J, Chute JP, Rizzieri D, Munchhof M, VanArsdale T, Beachy PA, Reya T: Hedgehog signalling is essential for maintenance of cancer stem cells in myeloid leukaemia. Nature 2009, 458:776-779.

44. Santini R, Vinci MC, Pandolfi S, Penachioni JY, Montagnani V, Olivito B, Gattai R, Pimpinelli N, Gerlini G, Borgognoni L, Stecca B: Hedgehog-GLI signaling drives self-renewal and tumorigenicity of human melanoma-initiating cells. Stem Cells 2012, 30:1808-1818.

45. Park KS, Martelotto LG, Peifer M, Sos ML, Karnezis AN, Mahjoub MR, Bernard K, Conklin JF, Szczepny A, Yuan J, Guo R, Ospina B, Falzon J, Bennett S, Brown TJ, Markovic A, Devereux WL, Ocasio CA, Chen JK, Stearns T, Thomas RK, Dorsch M, Buonamici S, Watkins DN, Peacock CD, Sage J: A crucial requirement for Hedgehog signaling in small cell lung cancer. Nat Med 2011, 17:1504-1508.

46. Varnat F, Duquet A, Malerba M, Zbinden M, Mas C, Gervaz P, Ruiz i Altaba A: Human colon cancer epithelial cells harbour active HEDGEHOG-GLI signalling that is essential for tumour growth, recurrence, metastasis and stem cell survival and expansion. EMBO Mo/ Med 2009, 1:338-351.

47. Kinzler KW, Bigner SH, Bigner DD, Trent JM, Law ML, O'Brien SJ, Wong AJ, Vogelstein B: Identification of an amplified, highly expressed gene in a human glioma. Science 1987, 236:70-73.

48. Dierks C, Grbic J, Zirlik K, Beigi R, Englund NP, Guo GR, Veelken H, Engelhardt M, Mertelsmann R, Kelleher JF, Schultz P, Warmuth M: Essential role of stromally induced hedgehog signaling in B-cell malignancies. Nat Med 2007, 13:944-951.

49. O'Toole SA, Swarbrick A, Sutherland RL: The Hedgehog signalling pathway as a therapeutic target in early breast cancer development. Expert Opin Ther Targets 2009, 13:1095-1103.

50. Oro AE, Higgins KM, Hu Z, Bonifas JM, Epstein EH Jr, Scott MP: Basal cell carcinomas in mice overexpressing sonic hedgehog. Science 1997, 276:817-821.

51. Xie J, Johnson RL, Zhang X, Bare JW, Waldman FM, Cogen PH, Menon AG, Warren RS, Chen LC, Scott MP, Epstein EH Jr: Mutations of the PATCHED gene in several types of sporadic extracutaneous tumors. Cancer Res 1997,
57:2369-2372

52. Vorechovsky l, Benediktsson KP, Toftgard R: The patched/hedgehog/ smoothened signalling pathway in human breast cancer: no evidence for H133Y SHH, PTCH and SMO mutations. Eur J Cancer 1999, 35:711-713.

53. Naylor TL, Greshock J, Wang Y, Colligon T, Yu QC, Clemmer V, Zaks TZ, Weber $\mathrm{BL}$ : High resolution genomic analysis of sporadic breast cancer using array-based comparative genomic hybridization. Breast Cancer Res 2005, 7:R1186-1198.

54. Nessling M, Richter K, Schwaenen C, Roerig P, Wrobel G, Wessendorf S, Fritz B, Bentz M, Sinn HP, Radlwimmer B, Lichter P: Candidate genes in breast cancer revealed by microarray-based comparative genomic hybridization of archived tissue. Cancer Res 2005, 65:439-447.

55. Ding L, Ellis MJ, Li S, Larson DE, Chen K, Wallis JW, Harris CC, McLellan MD, Fulton RS, Fulton LL, Abbott RM, Hoog J, Dooling DJ, Koboldt DC, Schmidt H, Kalicki J, Zhang Q, Chen L, Lin L, Wendl MC, McMichael JF, Magrini VJ, Cook L, McGrath SD, Vickery TL, Appelbaum E, Deschryver K, Davies S, Guintoli T, Lin $\mathrm{L}$, et al: Genome remodelling in a basal-like breast cancer metastasis and xenograft. Nature 2010, 464:999-1005.

56. Kubo M, Nakamura M, Tasaki A, Yamanaka N, Nakashima H, Nomura M, Kuroki $\mathrm{S}$, Katano M: Hedgehog signaling pathway is a new therapeutic target for patients with breast cancer. Cancer Res 2004, 64:6071-6074.

57. O'Toole SA, Machalek DA, Shearer RF, Millar EK, Nair R, Schofield P, McLeod D, Cooper CL, McNeil CM, McFarland A, Nguyen A, Ormandy CJ, Qiu MR, Rabinovich B, Martelotto LG, Vu D, Hannigan GE, Musgrove EA, Christ D, Sutherland RL, Watkins DN, Swarbrick A: Hedgehog overexpression is associated with stromal interactions and predicts for poor outcome in breast cancer. Cancer Res 2011, 71:4002-4014.

58. Wolf I, Bose S, Desmond JC, Lin BT, Williamson EA, Karlan BY, Koeffler HP: Unmasking of epigenetically silenced genes reveals DNA promoter methylation and reduced expression of PTCH in breast cancer. Breast Cancer Res Treatment 2007, 105:139-155.

59. Cui W, Wang LH, Wen YY, Song M, Li BL, Chen XL, Xu M, An SX, Zhao J, Lu YY, Mi $X Y$, Wang EH: Expression and regulation mechanisms of Sonic Hedgehog in breast cancer. Cancer Sci 2010, 101:927-933.

60. ten Haaf A, Franken L, Heymann C, von Serenyi S, Cornelissen C, de Hoon JP, Veeck J, Luscher B, Knuchel R, Dahl E: Paradox of sonic hedgehog (SHH) transcriptional regulation: Alternative transcription initiation overrides the effect of downstream promoter DNA methylation. Epigenetics 2011, 6:465-477.

61. Pratap J, Wixted JJ, Gaur T, Zaidi SK, Dobson J, Gokul KD, Hussain S, van Wijnen AJ, Stein JL, Stein GS, Lian JB: Runx2 transcriptional activation of Indian Hedgehog and a downstream bone metastatic pathway in breast cancer cells. Cancer Res 2008, 68:7795-7802.

62. Caserta TM, Kommagani R, Yuan Z, Robbins DJ, Mercer CA, Kadakia MP: p63 overexpression induces the expression of Sonic Hedgehog. Mol Cancer Res 2006, 4:759-768.

63. Xuan Y, Lin Z: Expression of Indian Hedgehog signaling molecules in breast cancer. J Cancer Res Clin Oncol 2009, 135:235-240.

64. Souzaki M, Kubo M, Kai M, Kameda C, Tanaka H, Taguchi T, Tanaka M, Onishi H, Katano M: Hedgehog signaling pathway mediates the progression of non-invasive breast cancer to invasive breast cancer. Cancer Sci 2011, 102:373-381.

65. Ramaswamy B, Lu Y, Teng KY, Nuovo G, Li X, Shapiro CL, Majumder S: Hedgehog signaling is a novel therapeutic target in tamoxifen-resistant breast cancer aberrantly activated by PI3K/AKT pathway. Cancer Res 2012, 72:5048-5059

66. Berman DM, Karhadkar SS, Maitra A, Montes De Oca R, Gerstenblith MR, Briggs K, Parker AR, Shimada Y, Eshleman JR, Watkins DN, Beachy PA: Widespread requirement for Hedgehog ligand stimulation in growth of digestive tract tumours. Nature 2003, 425:846-851.

67. Karhadkar SS, Bova GS, Abdallah N, Dhara S, Gardner D, Maitra A, Isaacs JT, Berman DM, Beachy PA: Hedgehog signalling in prostate regeneration, neoplasia and metastasis. Nature 2004, 431:707-712.

68. Stecca B, Mas C, Clement V, Zbinden M, Correa R, Piquet V, Beermann F, Ruiz IAA: Melanomas require HEDGEHOG-GLI signaling regulated by interactions between GLI1 and the RAS-MEK/AKT pathways. Proc Nat/ Acad SCiUS A 2007, 104:5895-5900.

69. Yauch RL, Gould SE, Scales SJ, Tang T, Tian H, Ahn CP, Marshall D, Fu L, Januario T, Kallop D, Nannini-Pepe M, Kotkow K, Marsters JC, Rubin LL, de Sauvage FJ: A paracrine requirement for hedgehog signalling in cancer. Nature 2008 , 455:406-410. 
70. Chen W, Tang T, Eastham-Anderson J, Dunlap D, Alicke B, Nannini M, Gould S, Yauch R, Modrusan Z, DuPree KJ, Darbonne WC, Plowman G, de Sauvage FJ, Callahan CA: Canonical hedgehog signaling augments tumor angiogenesis by induction of VEGF-A in stromal perivascular cells. Proc Natl Acad Sci U S A 2011, 108:9589-9594.

71. Tian H, Callahan CA, DuPree KJ, Darbonne WC, Ahn CP, Scales SJ, de Sauvage FJ: Hedgehog signaling is restricted to the stromal compartment during pancreatic carcinogenesis. Proc Natl Acad Sci U S A 2009, 106:4254-4259.

72. Visbal AP, LaMarca HL, Villanueva H, Toneff MJ, Li Y, Rosen JM, Lewis MT: Altered differentiation and paracrine stimulation of mammary epithelial cell proliferation by conditionally activated Smoothened. Dev Biol 2011, 352:116-127.

73. Mukherjee S, Frolova N, Sadlonova A, Novak Z, Steg A, Page GP, Welch DR, Lobo-Ruppert SM, Ruppert JM, Johnson MR, Frost AR: Hedgehog signaling and response to cyclopamine differ in epithelial and stromal cells in benign breast and breast cancer. Cancer Biol Ther 2006, 5:674-683.

74. DeRose YS, Wang G, Lin YC, Bernard PS, Buys SS, Ebbert MT, Factor R, Matsen C, Milash BA, Nelson E, Neumayer L, Randall RL, Stijleman IJ, Welm BE, Welm $A L$ : Tumor grafts derived from women with breast cancer authentically reflect tumor pathology, growth, metastasis and disease outcomes. Nat Med 2011, 17:1514-1520.

75. Harris LG, Pannell LK, Singh S, Samant RS, Shevde LA: Increased vascularity and spontaneous metastasis of breast cancer by hedgehog signaling mediated upregulation of cyr61. Oncogene 2012, 31:3370-3380.

76. Thiery JP, Acloque H, Huang RY, Nieto MA: Epithelial-mesenchymal transitions in development and disease. Cell 2009, 139:871-890.

77. Blanco MJ, Moreno-Bueno G, Sarrio D, Locascio A, Cano A, Palacios J, Nieto MA: Correlation of Snail expression with histological grade and lymph node status in breast carcinomas. Oncogene 2002, 21:3241-3246.

78. Mani SA, Yang J, Brooks M, Schwaninger G, Zhou A, Miura N, Kutok JL, Hartwell K, Richardson AL, Weinberg RA: Mesenchyme Forkhead 1 (FOXC2) plays a key role in metastasis and is associated with aggressive basal-like breast cancers. Proc Natl Acad Sci U S A 2007, 104:10069-10074.

79. Sterling JA, Oyajobi BO, Grubbs B, Padalecki SS, Munoz SA, Gupta A, Story B, Zhao M, Mundy GR: The hedgehog signaling molecule Gli2 induces parathyroid hormone-related peptide expression and osteolysis in metastatic human breast cancer cells. Cancer Res 2006, 66:7548-7553.

80. Das S, Samant RS, Shevde LA: Hedgehog signaling induced by breast cancer cells promotes osteoclastogenesis and osteolysis. J Bio/ Chem 2011 286:9612-9622.

81. Heller E, Hurchla MA, Xiang J, Su X, Chen S, Schneider J, Joeng KS, Vidal M, Goldberg L, Deng H, Hornick MC, Prior JL, Piwnica-Worms D, Long F, Cagan R, Weilbaecher KN: Hedgehog signaling inhibition blocks growth of resistant tumors through effects on tumor microenvironment. Cancer Res 2012 72:897-907

82. Das S, Tucker JA, Khullar S, Samant RS, Shevde LA: Hedgehog signaling in tumor cells facilitates osteoblast-enhanced osteolytic metastases. PloS One 2012, 7:e34374.

83. Effects of chemotherapy and hormonal therapy for early breast cancer on recurrence and 15-year survival: an overview of the randomised trials. Lancet 2005, 365:1687-1717.

84. Kennecke H, Yerushalmi R, Woods R, Cheang MC, Voduc D, Speers CH, Nielsen TO, Gelmon K: Metastatic behavior of breast cancer subtypes. J Clin Oncol 2010, 28:3271-3277

85. Cooper MK, Porter JA, Young KE, Beachy PA: Teratogen-mediated inhibition of target tissue response to Shh signaling. Science 1998, 280:1603-1607.

86. Lipinski RJ, Hutson PR, Hannam PW, Nydza RJ, Washington IM, Moore RW Girdaukas GG, Peterson RE, Bushman W: Dose- and route-dependent teratogenicity, toxicity, and pharmacokinetic profiles of the hedgehog signaling antagonist cyclopamine in the mouse. Toxicol Sci 2008, 104:189-197.

87. ClinicalTrials.gov [http://clinicaltrials.gov/ct2/home]

88. Dlugosz A, Agrawal S, Kirkpatrick P: Vismodegib. Nat Rev Drug Discovery 2012, 11:437-438.

89. Sekulic A, Migden MR, Oro AE, Dirix L, Lewis KD, Hainsworth JD, Solomon JA, Yoo S, Arron ST, Friedlander PA, Marmur E, Rudin CM, Chang AL, Low JA,
Mackey HM, Yauch RL, Graham RA, Reddy JC, Hauschild A: Efficacy and safety of vismodegib in advanced basal-cell carcinoma. N Engl J Med 2012 366:2171-2179.

90. LoRusso PM, Rudin CM, Reddy JC, Tibes R, Weiss GJ, Borad MJ, Hann CL, Brahmer JR, Chang I, Darbonne WC, Graham RA, Zerivitz KL, Low JA, Von Hoff DD: Phase I trial of hedgehog pathway inhibitor vismodegib (GDC-0449) in patients with refractory, locally advanced or metastatic solid tumors. Clin Cancer Res 2011, 17:2502-2511.

91. Rudin CM, Hann CL, Laterra J, Yauch RL, Callahan CA, Fu L, Holcomb T, Stinson J, Gould SE, Coleman B, LoRusso PM, Von Hoff DD, de Sauvage FJ, Low JA: Treatment of medulloblastoma with hedgehog pathway inhibitor GDC-0449. N Engl J Med 2009, 361:1173-1178.

92. Dijkgraaf GJ, Alicke B, Weinmann L, Januario T, West K, Modrusan Z, Burdick D, Goldsmith R, Robarge K, Sutherlin D, Scales SJ, Gould SE, Yauch RL, de Sauvage FJ: Small molecule inhibition of GDC-0449 refractory smoothened mutants and downstream mechanisms of drug resistance. Cancer Res 2011, 71:435-444.

93. Kim J, Tang JY, Gong R, Kim J, Lee JJ, Clemons KV, Chong CR, Chang KS, Fereshteh M, Gardner D, Reya T, Liu JO, Epstein EH, Stevens DA, Beachy PA: Itraconazole, a commonly used antifungal that inhibits Hedgehog pathway activity and cancer growth. Cancer cell 2010, 17:388-399.

94. Lauth M, Bergstrom A, Shimokawa T, Toftgard R: Inhibition of GLI-mediated transcription and tumor cell growth by small-molecule antagonists. Proc Natl Acad Sci U S A 2007, 104:8455-8460.

95. Hyman JM, Firestone AJ, Heine VM, Zhao Y, Ocasio CA, Han K, Sun M, Rack PG, Sinha S, Wu JJ, Solow-Cordero DE, Jiang J, Rowitch DH, Chen JK: Smallmolecule inhibitors reveal multiple strategies for Hedgehog pathway blockade. Proc Natl Acad Sci U S A 2009, 106:14132-14137.

96. Kim J, Lee JJ, Kim J, Gardner D, Beachy PA: Arsenic antagonizes the Hedgehog pathway by preventing ciliary accumulation and reducing stability of the Gli2 transcriptional effector. Proc Natl Acad Sci U S A 2010, 107:13432-13437.

97. Beauchamp EM, Ringer L, Bulut G, Sajwan KP, Hall MD, Lee YC, Peaceman D, Ozdemirli M, Rodriguez O, Macdonald TJ, Albanese C, Toretsky JA, Uren A: Arsenic trioxide inhibits human cancer cell growth and tumor development in mice by blocking Hedgehog/GLI pathway. J Clin Invest 2011, 121:148-160

98. Stanton BZ, Peng LF, Maloof N, Nakai K, Wang X, Duffner UL, Taveras KM, Hyman JM, Lee SW, Koehler AN, Chen JK, Fox JL, Mandinova A, Schreiber SL: A small molecule that binds Hedgehog and blocks its signaling in human cells. Nat Chem Biol 2009, 5:154-156.

99. Olive KP, Jacobetz MA, Davidson CJ, Gopinathan A, Mclntyre D, Honess D, Madhu B, Goldgraben MA, Caldwell ME, Allard D, Frese KK, Denicola G, Feig C, Combs C, Winter SP, Ireland-Zecchini H, Reichelt S, Howat WJ, Chang A, Dhara M, Wang L, Rückert F, Grützmann R, Pilarsky C, Izeradjene K, Hingorani SR, Huang P, Davies SE, Plunkett W, Egorin M, et al:: Inhibition of Hedgehog signaling enhances delivery of chemotherapy in a mouse model of pancreatic cancer. Science 2009, 324:1457-1461.

100. Slamon DJ, Leyland-Jones B, Shak S, Fuchs H, Paton V, Bajamonde A, Fleming T, Eiermann W, Wolter J, Pegram M, Baselga J, Norton L: Use of chemotherapy plus a monoclonal antibody against HER2 for metastatic breast cancer that overexpresses HER2. N Engl J Med 2001, 344:783-792.

101. Nolan-Stevaux O, Lau J, Truitt ML, Chu GC, Hebrok M, Fernandez-Zapico ME, Hanahan D: GLI1 is regulated through Smoothened-independent mechanisms in neoplastic pancreatic ducts and mediates PDAC cell survival and transformation. Genes Dev 2009, 23:24-36.

102. Bissell MJ, Hines WC: Why don't we get more cancer? A proposed role of the microenvironment in restraining cancer progression. Nat Med 2011, 17:320-329.

\section{doi:10.1186/bcr3401}

Cite this article as: Hui M, et al.: The Hedgehog signalling pathway in breast development, carcinogenesis and cancer therapy. Breast Cancer Research 2013, 15:203. 